\title{
Effect of the aqueous extract of Sida cordifolia on liver regeneration after partial hepatectomy ${ }^{1}$
}

\author{
Efeito do extrato aquoso de Sida cordifolia na regeneração hepática após \\ hepatectomia parcial
}

\author{
Renata Lemos Silva², Gustavo Barreto de Melo², Valdinaldo Aragão de Melo ${ }^{3}$, Ângelo Roberto Antoniolli ${ }^{4}$, Paulo Roberto \\ Teixeira Michellone ${ }^{5}$, Sérgio Zucoloto ${ }^{6}$, Maria Aparecida Neves Cardoso Picinato ${ }^{7}$, Clarice Fleury Fina Franco ${ }^{7}$, Gustavo \\ de Assis Mota ${ }^{8}$, Orlando de Castro e Silva ${ }^{9}$
}

1. Study performed in the Laboratory of Biochemistry of Liver Transplantation Unit of Division of Gastroenterology of the Departament of Surgery and Anatomy of Ribeirão Preto Faculty of Medicine-University of São Paulo (FMRP - USP), Brazil.

2. Graduate student of Federal University of Sergipe, Brazil.

3. Associate Professor of the Department of Medicine, Federal University of Sergipe, Brazil.

4. Associate Professor of the Department of Physiology, Federal University of Sergipe, Brazil.

5. Associate Professor of the Marília Faculty of Medicine (FAMEMA), São Paulo, Brazil.

6. Full Professor of the Department of Pathology, (FMRP-USP), Brazil.

7. Biomedical of Laboratory of Biochemistry of Liver Transplantation Unit of the Departament of Surgery and Anatomy, (FMRP-USP), Brazil.

8. MD, Assistant of the Department of Surgery and Anatomy, (FMRP-USP), Brazil

9. Full Professor and Head of Division of Gastroenterology of the Department of Surgery and Anatomy, (FMRP-USP), Brazil.

\begin{abstract}
Purpose: The use of medicinal plants for the treatment of human diseases has increased worldwide. Many of them are used by oral administration and, after absorption, may affect many organs. Therefore, this study aimed at assessing the effects of the aqueous extract of Sida cordifolia leaves, popularly known in Brazil as "malva-branca", on liver regeneration. Methods: Twenty rats were divided into four groups: control, Sida100, Sida200 and Sida400 groups. All animals were submitted to oral administration of distilled water, 100,200 and $400 \mathrm{mg} / \mathrm{kg}$ of the aqueous extract of Sida cordifolia, respectively. Immediately after this, they underwent $67 \%$ partial hepatectomy. Twenty four hours later, their livers were removed. Hepatic regeneration was assessed by immunohistochemical staining for proliferating cell nuclear antigen (PCNA) using the PC-10 monoclonal antibody. Results: Sida100 and Sida200 groups disclosed higher liver regeneration indices than control group ( $<<0.001$ and $\mathrm{p}<0.05$, respectively). Conclusion: The aqueous extract of Sida cordifolia stimulates liver regeneration after $67 \%$ partial hepatectomy in rats.
\end{abstract}

Key words: Partial Hepatectomy. Liver Regeneration. Sida cordifolia. Medicinal Plant.

\section{RESUMO}

Introdução: O uso de plantas medicinais para o tratamento de patologias humanas tem aumentado em todo mundo. Muitas delas são usadas por administração oral, e após a absorção podem afetar muitos órgãos. Objetivo: Esse estudo, tem como objetivo verificar o efeito do extrato aquoso de Sida cordifolia, popularmente conhecida no Brasil como "malva-branca", na regeneração hepática. Métodos: Vinte ratos foram divididos em 4 grupos: controle, Sida 100, Sida 200 e Sida 400 . Os animais foram submetidos a administração oral de água destilada, 100, 200 e $400 \mathrm{mg} / \mathrm{kg}$ de extrato aquoso de Sida cordifolia, respectivamente. Imediatamente após, foi realizada hepatectomia parcial $67 \%$. Vinte quatro horas após, os fígados foram removidos. A regeneração hepática foi avaliada por imunohistoquímica (PCNA), usando o anticorpo monoclonal PC-10. Resultados: Os grupos Sida100 e Sida200 mostraram índices de regeneração hepática maiores que o grupo controle ( $\mathrm{p}<0.001$ e $\mathrm{p}<0.05$, respectivamente). Conclusão: O extrato aquoso de Sida cordifolia estimula a regeneração hepática após hepatectomia parcial a $67 \%$ em ratos.

Descritores: Hepatectomia Parcial. Regeneração Hepática. Sida cordifolia. Planta Medicinal. 


\section{Introduction}

Sida cordifolia L. (Malvaceae) is popularly known as "malva-branca" (white mallow) or "malva-branca-sedosa" (silky white mallow) in Brazil. It grows as a bush of up to 2 $\mathrm{m}$ in height. The leaves are light green, cordiform, serrated and oval-elongated, and the pedunculated flowers are arranged in axillary or terminal racemes. In traditional medicine, the plant is used for the treatment of stomatitis, blenorrhea, asthmatic bronchitis and nasal congestion ${ }^{1}$. In Brazil, it is also used due to its anti-inflammatory properties. Some studies have demonstrated the presence in the leaves of sympathomimetic amines, ephedrine and pseudoephedrine, vasocinone ${ }^{2}$ and vasicine as major alkaloids ${ }^{3}$. Other studies also showed the presence of fatty oils, steroids, resin, resin acids, mucin and potassium nitrate in the plant ${ }^{4}$. The effectiveness of the extract of Sida cordifolia leaves as analgesic, anti-inflammatory (inhibition of prostaglandin synthesis) and hypoglycaemic has been reported ${ }^{4,1}$. Considering that there are no studies defining the effects of this plant on liver, this research aimed at assessing the effects of Sida cordifolia leaves on liver regeneration after $67 \%$ partial hepatectomy in rats.

\section{Methods}

- Plant material and preparation of the aqueous extract - Sida cordifolia leaves (identified by Dr C. Dias Silva Jr.; voucher no. 30171, deposited in the Department of Biology at Universidade Federal de Sergipe) were collected outside the blossoming period from the Live Pharmacy of Aracaju, Brazil. The leaves were dried in an oven with air renewal and circulation (model MA-037) at $37^{\circ} \mathrm{C}$ until complete dehydration. Dried Sida cordifolia leaves were triturated in a blender until a finely granulated powder was obtained. The extract was got from this powder $(100 \mathrm{~g})$ by adding distilled water $(3: 10 \mathrm{w} / \mathrm{v})$ under constant shaking for $4 \mathrm{~h}$ at $35^{\circ} \mathrm{C}$, followed by filtration ( $\mathrm{pH} \mathrm{6.0)}$. The filtrate was lyophilized (aqueous extract) and stored at $5^{\circ} \mathrm{C}$, yielding $16.2 \mathrm{~g}(16.2 \%)$ of lyophilized active material. At the time of use, the extract was resuspended in distilled water at the desired concentrations.

- Animals - The study was carried out on 20 male Wistar albino rats (180 to $230 \mathrm{~g}$ ). They were fed with a standard pellet diet and water ad libitum. All animals were randomly assigned to 4 groups, which consisted of 5 rats each. Control group animals were submitted to oral administration of distilled water at the time of surgery. Rats of Sida100, Sida200 and Sida400 groups underwent partial hepatectomy and oral administration of 100,200 and $400 \mathrm{mg} / \mathrm{kg}$ of the aqueous extract of Sida cordifolia.

- Surgical procedure - All operations were performed under ether anesthesia as it is not hepatotoxic. They always happened at the same time in order to avoid the influence of the changes in circadian cycle. The median and left lateral lobes of the liver (corresponding to $67 \%$ of the organ) were excised ${ }^{5}$. After surgery, the rats were on a normal diet for the whole experimental period. Twenty four hours later, they underwent a new operation to remove the remaining liver. Then, they were sacrificed.

- Liver regeneration analysis - Liver regeneration was evaluated by immunohistochemical staining for proliferating cell nuclear antigen (PCNA) using monoclonal primary antiPCNA antibody (PC-10; DAKO A/S, Glostrup, Denmark) on formalin-fixed and paraffin-embedded liver tissues ${ }^{6}$. Sections were cut at $4 \mu \mathrm{m}$, mounted on poly-L-lysine-coated glass slides, deparaffinized, rehydrated in an increasing alcohol series, placed in PBS, and treated with $2 \%$ hydrogen peroxide in methanol for $15 \mathrm{~min}$ to block endogenous peroxidase activity. Nonspecific protein binding was blocked by preincubation with $5 \%$ normal horse serum diluted in PBS for $30 \mathrm{~min}$. This was followed by incubation with PC-10 monoclonal primary antibody, diluted 1:40 in PBS for 120 $\mathrm{min}$ at $25^{\circ} \mathrm{C}$. The sections were then incubated for $35 \mathrm{~min}$ with a biotinylated horse antimouse immunoglobulin. The reaction product was detected with an avidin-biotinperoxidase complex and diaminobenzidine was used as a chromogen substrate. Positive and negative controls were used to assess and control the staining procedure. Sections were examined blindly at high power (400X), and 20 fields were chosen at random. Nuclear labeling indices for PCNA (positive nuclei/total number of counted nuclei) were determined by evaluation of at least 1,000 hepatocyte nuclei.

- Statistical analysis of data - Mann-Whitney's test was used to compare the results between the groups, with the level of significance set to $5 \%$.

\section{Results}

The results are shown in Table 1.

TABLE 1 - Detailed data showing individual values as well as means and standard error of mean of hepatocyte regeneration index $(\%)$ in the absence and in the presence of different concentrations of the aqueous extract of Sida cordifolia $(100,200$ and $400 \mathrm{mg} / \mathrm{kg})$

\begin{tabular}{lllllll}
\hline & Rat 1 & Rat 2 & Rat 3 & Rat 4 & Rat 5 & Mean \pm SEM \\
\hline Control & $38 \%$ & $22 \%$ & $40 \%$ & $24 \%$ & $27.2 \%$ & $30.24 \pm 8.2$ \\
Sida100 & $91.2 \%$ & $94.12 \%$ & $82.72 \%$ & $92.98 \%$ & $90 \%$ & $90.25 \pm 5.16$ \\
Sida200 & $40.3 \%$ & $70.46 \%$ & $63.24 \%$ & $35.34 \%$ & $43.54 \%$ & $50.6 \pm 15.35$ \\
Sida400 & $41.6 \%$ & $31.6 \%$ & $39.8 \%$ & $26.4 \%$ & $64 \%$ & $40.7 \pm 14.4$ \\
\hline
\end{tabular}

$* \mathrm{p}<0.001$ vs. Control

$* * \mathrm{p}<0.05$ vs. Control 


\section{Discussion}

Hepatocyte regeneration index was significantly increased in Sida100 group when compared to control group $(\mathrm{p}<0.001)$ and all other groups. Sida200 group also disclosed a statistically significant increase in regeneration rate in comparison to control group $(\mathrm{p}<0.05)$. After many studies, some regulation factors that trigger or control the liver regeneration phenomenon had their effect demonstrated on hepatocyte proliferation. The elucidation of the mechanisms involved in this phenomenon has been possible through cultured rat hepatocytes and gene expression pattern after partial hepatectomy. Among these substances, there are the ones that act directly or indirectly on DNA synthesis. They are called mitogens and co-mitogens, respectively. The main mitogens are: hepatocyte growth factor (HGF), epidermal growth factor (EGF), transforming growth factor alpha (TGFá) and acidic fibroblast growth factor (aFGF). The co-mitogens are: hepatic stimulatory substance (HSS), norepinephrine and alpha-1 adrenoreceptors, vasopressin, angiotensin I and II, insulin, glucagon, estrogens, testosterone, immunosuppressive agents, bradykinin, angiotensin-converting enzyme inhibitors, tumor necrosis factor alpha (TNFá) and prostaglandins ${ }^{6,7}$. In 1999, it was disclosed that the extract of Sida cordifolia leaves, which was proved to be antiinflammatory, analgesic and hypoglycaemic, augments insulin release after its administration ${ }^{4}$. The alcoholic extract of the plant, at 150,300 and $600 \mathrm{mg} / \mathrm{kg}$, was orally administered to Wistar rats. Then it was noticed a significant decrease in glucose levels. These findings suggested that Sida cordifolia stimulates insulin release by pancreatic â cells, acting like sulphonylureas. Knowing that insulin acts as an important co-mitogen ${ }^{8,9}$ it can be raised the hypothesis that the augmented release of this hormone, stimulated by Sida cordifolia, can exert a permissive role in the hepatocellular synthesis of DNA and, consequently, in liver regeneration process. It is important to mention that this is only one idea to explain how the aqueous extract of Sida cordifolia leaves causes stimulation of liver regeneration. Due to the fact that hepatocyte proliferation involves many different factors, it is important that more studies are carried out in order to establish other mechanisms to explain these results. These results show that the aqueous extract of Sida cordifolia leaves at single oral doses of 100 and $200 \mathrm{mg} / \mathrm{kg}$ causes a high liver regeneration rate in rats submitted to partial hepatectomy.

\section{References}

1. Franzotti EM, Santos CVF, Rodrigues HMSL, Mourão RHV, Andrade MR, Antoniolli AR. Anti-inflammatory, analgesic activity and acute toxicity of Sida cordifolia L. (Malva-branca). J Ethnopharmacol. 2000;72: 273-8.

2. Ghosal S, Chauhan RRPS, Mehta R. Alkaloids of Sida cordifolia. Phytother. Chem.1975; 14: 830-2.

3. Gunatilaka AAL, Sotheeswaran S, Balasubramanian S, Chandrasekara AI, Sriyani HTB. Studies on medicinal plants of Sri Lanka. Planta Med. 1980;39: 66-72.

4. Kanth VR, Diwan PV. Analgesic, antiinflammatory and hypoglycaemic activities of Sida cordifolia. Phytother Res. 1999; 13: 75-7.

5. Higgins GM,Anderson RM. 1931. Experimental pathology of the liver: restoration of liver of the white rat following partial surgical removal. Arch Pathol. 1931; 12: 186-202.

6. Ramalho FS. Monografia de Pós-graduação, Faculdade de Medicina de Ribeirão Preto - Universidade de São Paulo; 2000.

7. Court FG, Wemyss-Holden SA, Dennison AR, Maddern GJ. The mystery of liver regeneration. Br J Surg. 2002; 89:1089-95.

8. Bucher NLR, Swaffield MN. Rate of incorporation of labeled thymidine into deoxyribonucleic acid of regenerating rat liver in relation to amount of liver excised. Cancer Res. 1964; 24:1611-25.

9. Castro e Silva Jr O, Ceneviva R, Ferreira AL, Foss MC, Delucca FL. Liver trophism in dogs made diabetic by total pancreatectomy or alloxan administration. Braz $\mathrm{J}$ Med Biol Res. 1987; 20:269-76.

\section{Correspondence:}

Orlando de Castro e Silva Jr.

Rua Campos Salles, 809 - $9^{\circ}$ andar. CEP: 14015-110

Centro, Ribeirão Preto - SP - Brazil.

Email: orlando@fmrp.usp.br
Conflict of interest: none Financial source: CNPq and FAPESP

\section{How to cite this article}

Silva RL, Melo GB, Melo VA, Antoniolli AR, Michellone PRT, Zucoloto S, Picinato MANC, Franco CFF, Mota GA, Castro e Silva O. Effect of the aqueous extract of Sida cordifolia on liver regeneration after partial hepatectomy. Acta Cir Bras. [serial on the Internet] 2006;21 Suppl 1. Available from URL: http://www.scielo.br/acb 